\title{
Effect of long-term nutrient management on soil organic carbon sequestration in rice-rice-fallow rotation
}

\author{
Umme Aminun Naher*, M. B. Hossain, M. M. Haque, M. Maniruzzaman, \\ A. K. Choudhury and J. C. Biswas \\ Soil Science Division, Bangladesh Rice Research Institute, Gazipur, 1701, Bangladesh
}

\begin{abstract}
A study was conducted on long-term (for 31 years) rice-rice-fallow cropping sequence to determine the effect of balanced chemical fertilizer and integrated nutrient management (INM; chemical fertilizer + poultry manure 2 tonne $\mathrm{ha}^{-1}$ ) on soil organic carbon (SOC) sequestration. $C$ mineralization rate $(k)$, microbial population, SOC and $C$ content in the mean water stable soil aggregate (MWDw) were measured from field soil. The $C$ dynamics was described using DSSAT crop and DNDC models. INM increased soil bacteria and improved SOC stock by $27.98 \%$, although $C$ loss was higher with this treatment. A decreasing trend of bacterial population and SOC was observed in the balanced chemical fertilizer $(15 \%)$ and fertilizer control $(46 \%)$ treatments compared to initial soil. A positive correlation $(r=0.94)$ was found between $C$ content of MWDw and soil bacteria population, which provided evidence of vital contribution of soil bacteria for SOC sequestration. In INM treatment, $k$ (incubation study) was 0.011 tonne year ${ }^{-1}$, and it was less than DNDC- and DSSAT-generated data. However, $k$ value (0.010 tonne year $\left.{ }^{-1}\right)$ obtained in the incubation study of the balanced chemical fertilizer was similar to DNDC model data. An increasing trend of paddy yield (10 years) was observed in INM compared to balanced chemical fertilizer. In conclusion, microbial population, SOC sequestration and crop yield were high with INM. For sustainable rice production and $C$ sequestration, INM is superior to balanced chemical fertilizer. Between two models used, DNDC is better for prediction of SOC balance.
\end{abstract}

Keywords: Bacterial population, carbon stock, fallow, poultry manure, rice.

SoIL organic matter (SOM) is the storehouse of many mineralizable nutrients for plant growth and development. It improves cation exchange capacity, buffering system, structure and aggregate stability of the soil ${ }^{1}$. Healthy soil biology and ecosystem depend on SOM content. Soil is one of the greatest carbon (C) reservoirs of this planet. It has potential for $\mathrm{C}$ sequestration and thus

\footnotetext{
*For correspondence. (e-mail: naher39@gmail.com)
}

slows down global warming by reducing $\mathrm{CO}_{2}$ emissions depending on environmental conditions ${ }^{2,3}$. Soil biochemical and physical processes are governed by the environment and management practices such as methods of cultivation, types of crop, nutrient management practices, temperature, moisture, soil texture, etc. ${ }^{4}$.

Microbial activities are directly related to $\mathrm{SOM}$ decomposition and soil $\mathrm{C}$ loss as $\mathrm{CO}_{2}$ and methane $\left(\mathrm{CH}_{4}\right)$. All these $\mathrm{C}$ loss phenomena are related to the availability of $\mathrm{C}$ substrates and decomposition of added SOM, which is more complicated in association with crops in a cropping system rather than single cropping pattern. For example, soil in a rice-rice-fallow cropping system remains flooded during most of crop growth period. However, the crop experiences dissimilar temperature and rainfall during different growing seasons. After harvest of the first-season crop, about $10-20 \mathrm{~cm}$ of crop residue with root remains in the field, which is incorporated with the soil during land preparation for the next crop. So, in the rice-rice-fallow cropping pattern, some amount of crop residue is added to the soil in each season. Decomposition rate of this residue is faster in summer compared to winter as temperature and rainfall favour the process. Another important factor is fertilizer management practice in which $\mathrm{C}$ mineralization pattern will vary depending on organic and inorganic amendments. Considering temperature, rainfall and fertilizer management practices, it is complex to determine SOM turnover in a cropping system. Models such as DSSAT $^{5-7}$ and DNDC $^{8}$ can be used to determine approximate soil $\mathrm{C}$ dynamics under wide climate and management practices, where crops are grown in rotations over the years. Hence, the objectives of the present study were: (i) to determine the effect of different nutrient management practices on soil $\mathrm{C}$ mineralization and (ii) to evaluate $\mathrm{C}$ dynamics using DSSAT and DNDC models in a rice-rice cropping pattern after 46 years of crop cultivation.

\section{Materials and methods}

\section{Field history and nutrient management}

The study site is located at Bangladesh Rice Research Institute farm, Gazipur $\left(29.54^{\circ} \mathrm{N}, 90.24^{\circ} \mathrm{E}\right)$, Dhaka, 


\section{RESEARCH ARTICLES}

Bangladesh. The climate of the site is tropical humid, with a dry season from November to February. Annual rainfall is $2200 \mathrm{~mm}$ and annual mean temperature is $29^{\circ} \mathrm{C}$. Mean temperature for the warmest and coolest months varies by less than $5^{\circ} \mathrm{C}$ and mean annual relative humidity is $89 \%$. The soil is grey terrace soil, clay loam in texture. Initially, i.e. in 1985, SOM was $1.14 \%$ and total nitrogen was $0.08 \%$. In this study, yearly rice was grown in two seasons as irrigated Boro (January-May) and rainfed T. Aman (July-December). Three treatment combinations considered for this study were: $T_{1}$ : full chemical fertilizer (balanced doses of N, P, K, S and Zn); $T_{2}$ : integrated nutrient management (INM), chemical fertilizer with 2 tonne ha ${ }^{-1}$ poultry manure (PM; applied during the last 10 years), and $T_{3}$ : fertilizer control treatment. Chemical fertilizer doses $\left(\mathrm{kg} \mathrm{ha}^{-1}\right) \mathrm{N}-\mathrm{P}-\mathrm{K}-\mathrm{S}-\mathrm{Zn}$ were applied @ 138-10-80-20-5 and 100-10-80-20-5 for dry season irrigated rice (Boro) and rainfed rice (T. Aman) respectively. The fertilizer rate was calculated following soil test results-based nutrient requirement with a yield target of 7.5 tonne $\mathrm{ha}^{-1}$ for Boro and 6.5 tonne ha $\mathrm{h}^{-1}$ for $\mathrm{T}$. Aman respectively.

\section{Carbon mineralization rate (incubation study)}

After harvest of 62 crop, soil samples $(15 \mathrm{~cm})$ were collected for incubation study to determine $\mathrm{C}$ mineralization rate at annual mean temperature. Briefly, samples were prepared by air-drying and sieving $(2 \mathrm{~mm})$ to remove root fragments. Soils of each treatment $(3 \mathrm{~kg})$ were taken into separate plastic pots and kept in an incubator at $28^{\circ} \pm 2{ }^{\circ} \mathrm{C}$ temperature. Soil moisture was maintained as saturated. The incubation study was carried out for one month and $\mathrm{C}$ mineralization rate $(k)$ was calculated as

$$
k=2.303 \frac{\left(\log C_{0}-\log C\right)}{t},
$$

where $C_{0}$ is the initial $C$ content and $C$ at time $t$.

\section{Total bacterial population}

Bacterial population was determined from 0 to $15 \mathrm{~cm}$ soil depth using dilution and total plate count method in nutrient agar medium. A series of ten-fold dilutions was prepared up to $10^{-8}$ of $10 \mathrm{~g}$ soil and the bacterial populations were determined in nutrient agar plate following total plate count method ${ }^{9}$.

\section{Soil water stable aggregate}

Soil water stable aggregate was determined to check soil $\mathrm{C}$ sequestration among the treatments. Soil samples from 0 to $15 \mathrm{~cm}$ depth were used for aggregate analysis by wet sieving method. The classical procedure described by
Kemper and Rosenau ${ }^{10}$ was used to separate water-stable aggregates. In brief, $20 \mathrm{~g}$ of $4 \mathrm{~mm}$ air-dried soil samples was placed on the topmost sieve of a nest of three sieves of $2,0.59,0.30,0.149$ and $0.074 \mathrm{~mm}$ mesh size and pre-soaked in distilled water for $30 \mathrm{~min}$. Then, the nest of sieves was oscillated vertically in water 20 times, at $4 \mathrm{~cm}$ amplitude and at the rate of 1 oscillations/sec so that soil particles on the topmost sieve were always below the water surface during each oscillation. After wet-sieving, the water-stable soil materials left in each sieve were quantitatively transferred into beakers, dried in the oven at $50^{\circ} \mathrm{C}$ for $48 \mathrm{~h}$, weighed, and stored for later analysis. The soil organic carbon (SOC) content in each fraction was measured by Walkley and Black method ${ }^{11}$. Mean weight diameter of water-stable aggregate (MWDw) was calculated by the equation

$$
\mathrm{MWDw}=X_{i} \times W_{i},
$$

where $X_{i}$ is the mean diameter of the $i$ th sieve and $W_{i}$ is the amount of total aggregates in the $i$ th fraction.

\section{Model calibration and validation}

The crop rotation or sequence tool in DSSAT V4.5 was used to simulate long-term rice-rice-fallow crop production system. Experimental file was initiated using original field datasets of each treatment. Weather file was created from weather data obtained from Gazipur meteorological station. Agronomic management practices such as seeding, transplanting, seedling weight, fertilizer application, organic amendment and irrigation schedule were done according to model requirements for each season. DSSAT genetic crop coefficient parameters were adjusted separately using a default rice variety for both T. Aman and Boro rice. The model was calibrated and validated (RMSE and $d$ value) using original SOC data of the last 10 years for each treatment.

Fertilizer inputs, management practices, manure amendments, irrigation and flooding, crop rotation, land preparation and harvesting dates were fed to the model according to long-term experiment schedule. The SOC analysis data of different treatments were the base to calibrate the DNDC model. However, microbial activity index parameter was set at $1 \%$ for INM $\left(T_{2}\right), 0.6 \%$ for balanced fertilizer $\left(T_{1}\right)$ and $0.3 \%$ for the fertilizer control $\left(T_{3}\right)$ treatments. Total microbial populations were counted from different treatments using plate count method in nutrient agar medium (Table 1). During the calibration process, all parameters related to SOM and crop growth were chosen based on sample analysis in the laboratory.

\section{Statistical analysis}

Data obtained for $\mathrm{C}$ mineralization in the incubation study were analysed following complete randomized 
design. Evaluation of model performance was done based on comparison of the simulated values provided by the model with actual values obtained from field measurements. However, statistical model evaluation was done using correlation coefficient, mean ratio and mean difference (RMSE), and mean difference between observations and simulation.

\section{Results}

\section{Bacterial population and soil carbon mineralization}

Figure 1 shows total bacterial population and soil $\mathrm{C}$ fraction in the mean weight diameter of water-stable aggregates. Significantly high bacterial population was observed in the INM treatment, in which PM was added with chemical fertilizer during the last ten years. Application of balanced chemical fertilizer reduces bacterial population. The lowest bacteria population was found in control treatment, where none of the nutrients was added for 31 years. A similar trend of soil $\mathrm{C}$ fraction was found in the MWDw, which establishes a strong correlation $(r=0.94)$ between the two variables. Table 1 provides the result of $\mathrm{C}$ mineralization rate $(k)$. In the incubation study, $\mathrm{C}$ mineralization rate was high $\left(0.011\right.$ tonne year $\left.^{-1}\right)$ with INM followed by balanced chemical fertilizer $(0.010$ tonne year $\left.{ }^{-1}\right)$ and control (0.009 tonne year $\left.{ }^{-1}\right)$ treatments.

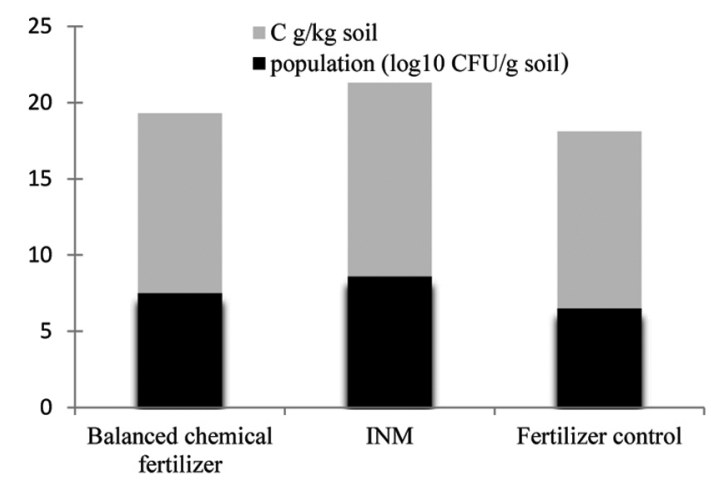

Figure 1. Effect of long-term nutrient management on soil total bacterial population and soil organic carbon (SOC) stock in rice-rice cropping sequence.

Table 1. Carbon mineralization rate under different fertilizer management practices (incubation study)

\begin{tabular}{lccc}
\hline & \multicolumn{3}{c}{$\begin{array}{c}\text { Carbon mineralization rate } \\
\left(k=\text { tonne year }^{-1}\right)\end{array}$} \\
\cline { 2 - 4 } Treatment & 0.009 & 0.005 & 0.007 \\
\hline Fertilizer control & 0.010 & 0.010 & 0.018 \\
Balanced chemical fertilizer & 0.011 & 0.020 & 0.030 \\
$\begin{array}{l}\text { Integrated nutrient management } \\
\quad \text { INM) }\end{array}$ & & & \\
\hline
\end{tabular}

A similar trend of $k$ value was obtained in both the tested models, i.e. highest $\mathrm{C}$ mineralization occurred with INM and lowest in the fertilizer control treatment. However $k$ values obtained using the DNDC and DSSAT models were very low and high for the chemical fertilizer control and INM respectively, compared to field soil incubation study. At balanced chemical fertilizer treatment, similar $k$ value was found in both the incubation study and using the DNDC model.

\section{Soil carbon sequestration}

Soil $\mathrm{C}$ content $\left(\mathrm{kg} \mathrm{ha}^{-1}\right)$ of the last 15 years was generated using the DSSAT model (Figure 2), which showed an increasing trend in INM and decreasing trend for balanced chemical fertilizer and control treatment. Table 2 shows soil $\mathrm{C}$ sequestration of the last 10 years in ricerice-fallow cropping sequence. In the field study, significantly high soil $\mathrm{C}$ stock (26.30 tonne $\mathrm{ha}^{-1}$ year $^{-1}$ ) was observed in INM followed by balanced chemical fertilizer (17.30 tonne $\mathrm{ha}^{-1}$ year $^{-1}$ ) and fertilizer control (10.95 tonne $\mathrm{ha}^{-1}$ year $^{-1}$ ) treatments compared to initial soil (20.55 tonne $\mathrm{ha}^{-1}$ year $^{-1}$ in year 1985). Similar trend of C stock was also generated in the DNDC and DSSAT models. However, both models generated some $\mathrm{C}$ stock value (30.5 tonne $\mathrm{ha}^{-1}$ year $^{-1}$ ) for INM, which was higher than the field-observed data. In the field observation, a negative $\mathrm{C}$ sequestration was recorded in the fertilizer control and balanced chemical fertilizer treatments; however, it was positive (127.86 kg ha $\mathrm{kear}^{-1}$ ) for INM. In case of the DNDC model, C sequestration for INM was $539 \mathrm{~kg} \mathrm{ha}^{-1}$ year $^{-1}$, followed by balanced chemical fertilizer treatment $\left(151.5 \mathrm{~kg} \mathrm{ha}^{-1}\right.$ year $\left.^{-1}\right)$ and the lowest was for fertilizer control treatment $\left(46.6 \mathrm{~kg} \mathrm{ha}^{-1} \mathrm{year}^{-1}\right)$. The $\mathrm{C}$ sequestration value was higher in the DSSAT model compared to the DNDC model.

\section{Carbon balance}

Carbon losses were determined using the DNDC model (Table 3). Total C loss was high in INM (1343 kg C ha ${ }^{-1}$ year $\left.^{-1}\right)$ compared to balanced chemical fertilizer $(866 \mathrm{~kg}$ $\mathrm{C} \mathrm{ha}^{-1}$ year $\left.^{-1}\right)$ and fertilizer control (236 kg C ha ${ }^{-1}$ year $\left.^{-1}\right)$ treatments. $\mathrm{C}$ loss was high in INM due to higher $\mathrm{CO}_{2}$, $\mathrm{CH}_{4}$ and $\mathrm{C}$ leaching compared to other treatments. The lowest $\mathrm{C}$ loss was observed in the fertilizer control treatment.

\section{Crop yield}

Figure 3 shows the annual (Boro $+\mathrm{T}$. Aman) paddy yield. The yield data of the last 10 years showed significantly higher paddy yield and an increasing trend in INM. However a yield plateau trend was observed in the balanced 

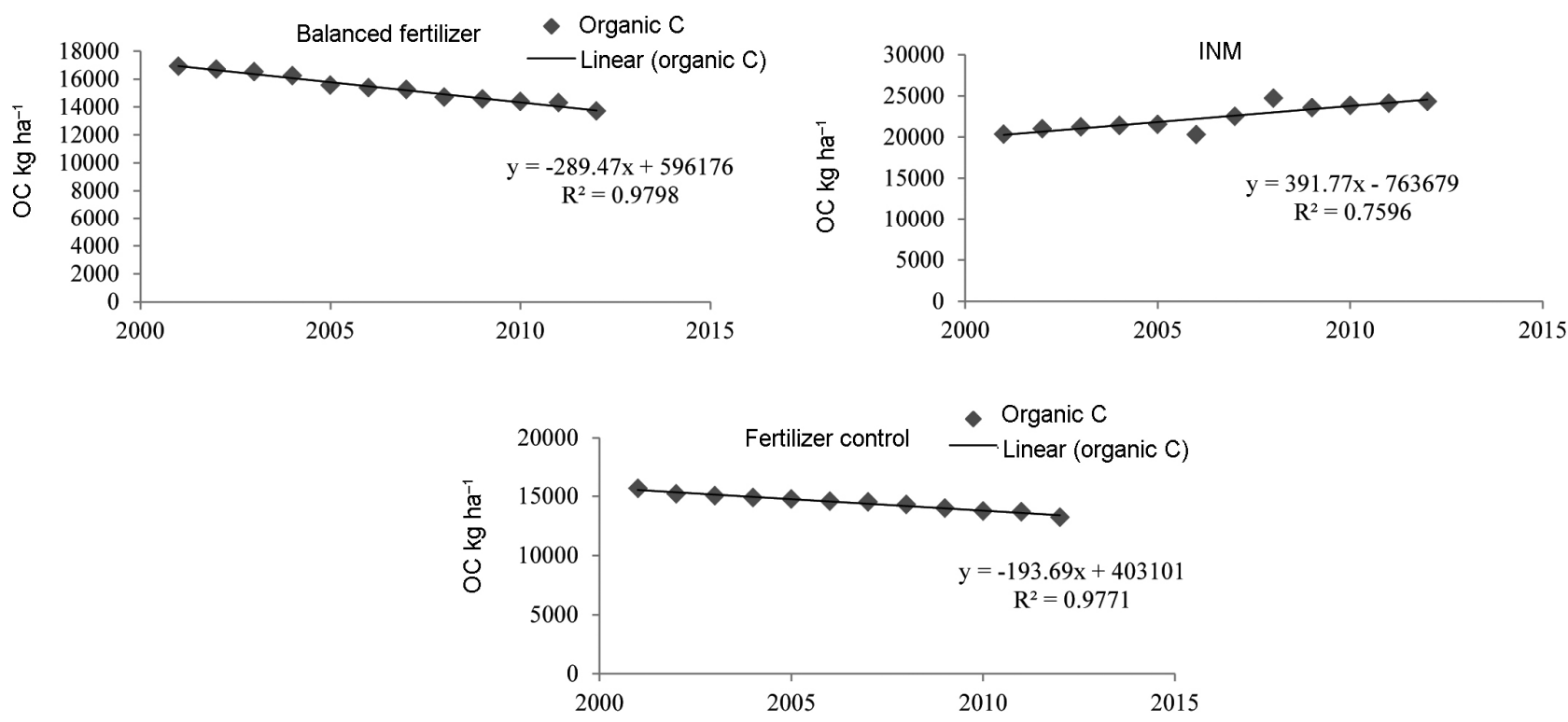

Figure 2. SOC content in rice-rice-fallow cropping pattern (last 15 years). Model: DSSAT, Index of agreement 0.91 .

Table 2. Carbon sequestration during the last 10 years in a rice-rice-fallow cropping sequence

\begin{tabular}{|c|c|c|c|c|c|c|}
\hline \multirow[b]{2}{*}{ Treatment } & \multicolumn{3}{|c|}{ Carbon stock (tonne ha ${ }^{-1}$ year $^{-1}$ ) } & \multicolumn{3}{|c|}{ Carbon sequestration $\left(\mathrm{kg} \mathrm{ha}^{-1}\right.$ year $\left.^{-1}\right)$} \\
\hline & Observed & DNDC & DSSAT & Observed & DNDC & DSSAT \\
\hline Fertilizer control & 10.95 & 10.7 & 18.4 & -213 & 46.6 & 149 \\
\hline Balanced fertilizer & 17.303 & 19.7 & 25.6 & -72.15 & 151.5 & 457 \\
\hline INM & 26.304 & 30.7 & 30.8 & 127.86 & 539 & 706 \\
\hline Initial soil & 20.55 & - & - & - & - & - \\
\hline
\end{tabular}

fertilizer treatment. The lowest paddy yield and yield decreasing trend were found in the fertilizer control treatment. In the long run, INM produced superior yield than balanced chemical fertilizer.

\section{Model evaluation}

Model evaluation was performed using SOC data of longterm rice-rice-fallow cropping sequence field experiment. Statistical analysis for root mean square error (RMSE), and mean difference between observations and simulation was performed (Table 4). Statistical values (nRMSE) obtained for INM and balanced chemical fertilizer treatment were within the range, and $d$ value gave the best fit for all the treatments for both models. However, values estimated using the DNDC model were closer to the observed data than the DSSAT crop model.

\section{Discussion}

Bacterial population may have significant role in SOC sequestration. The highest bacterial population and $\mathrm{C}$ sequestration were found in organic amended plots (INM) and the lowest in the fertilizer control treatment, where in the last 31 years no nutrient was added. Carbon mineralization in the flooded soil was mainly derived from labile $\mathrm{C}$ pools ${ }^{12}$ and SOC dynamics was governed by both biophysical and biological changes during microbial decomposition of organic matter ${ }^{13}$. The highest bacterial population and higher $\mathrm{C}$ sequestration in INM-treated plots might be a resultant effect of SOM and activity of soil bacteria. Wang et al. ${ }^{14}$ also found a strong positive correlation of bacterial abundance with total SOC accumulation, and reported an enhanced bioactivity with $\mathrm{C}$ stabilization. Moreover, MWDw play a considerable role in improving $\mathrm{C}$ sequestration. In the present study, SOC increased because of INM rather than balanced chemical (NPKSZn) fertilizations and without fertilizer application (control). Aggregate size fraction of $0.30 \mathrm{~mm}$ showed the highest SOC $\left(12.7 \mathrm{~g} \mathrm{~kg}^{-1}\right)$ in INM, whereas in the balanced chemical fertilizer treatment it was $11.8 \mathrm{~g} \mathrm{~kg}^{-1}$. So there might be a strong relationship for $\mathrm{C}$ sequestration in soil aggregate size and soil microbial activity, and it was enhanced due to organic amendment. A close relationship between the soil aggregate stability 
Table 3. Carbon losses from rice-rice-fallow cropping sequence since the last 10 years measured using the DNDC model

\begin{tabular}{lccccc}
\hline & \multicolumn{5}{c}{ Carbon loss $\left(\mathrm{kg} \mathrm{C} \mathrm{ha}^{-1}\right.$ year $\left.^{-1}\right)$} \\
\cline { 2 - 6 } Treatment & $\mathrm{CO}_{2}$ evolution & $\mathrm{CH}_{4}$ emission & C leaching & Run-off & Total \\
\hline Fertilizer control & 185 & 41 & 5 & 5 & 236 \\
Balanced chemical fertilizer & 691 & 143 & 16 & 16 & 866 \\
INM & 1281 & 232 & 27 & 14 & 1343 \\
\hline
\end{tabular}

Table 4. Statistical analysis of model-generated data for rice-ricefallow cropping sequence

\begin{tabular}{lccccc}
\hline & \multicolumn{2}{c}{ nRMSE } & & \multicolumn{2}{c}{$d$} \\
\cline { 2 - 3 } \cline { 5 - 6 } Treatment & DNDC & DSSAT & & DNDC & DSSAT \\
\hline INM & 7.9 & 20.9 & & 0.99 & 0.99 \\
Complete & 4.1 & 25.6 & & 0.99 & 0.98 \\
Control & 36 & 18 & & 0.95 & 0.99 \\
\hline
\end{tabular}

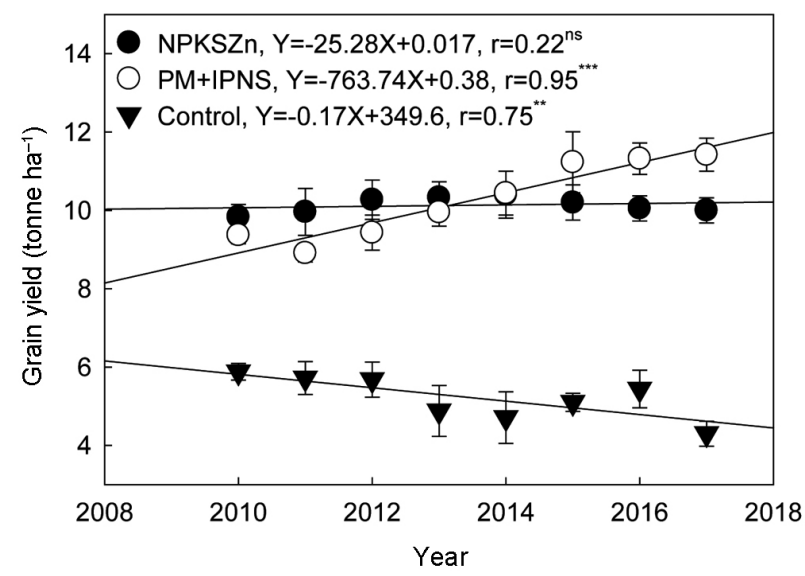

Figure 3. Effect of long-term nutrient management on rice yield.

index and SOM content has been reported in the literature $^{15-18}$.

In the present study, application of PM along with chemical fertilizers (INM) increased SOC stock considering initial soil status. Increased SOC by PM amendments was also reported by Are et al. ${ }^{19}$. The beneficial effects of organic amendments for enhancing soil $\mathrm{C}$ sequestration have been reported in the literature ${ }^{20,21}$. In the present study, SOC stock increased by $27.98 \%$ due to addition of $\mathrm{PM}$ at 2 tonne $\mathrm{ha}^{-1}$ in INM over the last 10 years. Adeleye et $a .^{22}$ found that the application of 10 tonne ha ${ }^{-1}$ PM increased SOC by $37.8 \%$. The SOC stock decreased by $46 \%$ in fertilizer control and $15 \%$ in balanced chemical fertilizer treatments compared to initial soil $\mathrm{C}$ content. The lowest soil $\mathrm{C}$ content in the fertilizer control soil might be due to less root biomass incorporation into the soil compared to balanced chemical fertilizer treatment. It is well known that balanced fertilization produces higher root biomass, and rice root biomass has a significant role in rice soil $\mathrm{C}$ sequestration. Carbon sequestration in ricerice-fallow cropping system was determined from origi- nal field study and simulated data obtained from model. Model-generated data also showed a negative balance of organic $\mathrm{C}$ in the control and balanced fertilizer-treated soils (Figure 2).

According to the DNDC model total carbon sequestration was $47 \mathrm{~kg} \mathrm{ha}^{-1}$ year $^{-1}$ in the control and $151 \mathrm{~kg} \mathrm{ha}^{-1}$ year $^{-1}$ in the chemical fertilizer-treated plots. Whereas it was $539 \mathrm{~kg} \mathrm{ha}^{-1}$ year $^{-1}$ in soil subject to INM. The incubation study result of $\mathrm{C}$ mineralization rate $(k)$ of the experimental field soil was comparable with modelgenerated data. Carbon mineralization rate was lower in the control plot compared to balanced chemical fertilizer treatment and INM. The highest $\mathrm{C}$ mineralization rate was obtained from INM and simulated $k$ value was higher in both tested models compared to that observed. The results obtained for $\mathrm{C}$ stock using the DNDC model were similar for fertilizer control and balanced chemical fertilizer treatments compared to the DSSAT cropping sequence model.

Carbon losses were determined using the DNDC model and highest $\mathrm{C}$ loss was found in INM followed by balanced chemical fertilizer applied soil (Table 3). Total SOC stocks were significantly different between INM and balance chemical fertilizer treatment during the study period. These results indicate that INM plays a critical role in maintaining SOC sequestration. It resulted in higher $\mathrm{C}$ sequestration compared to non-treated control. Addition of more root biomass $\mathrm{C}$ to the soil improved physico-chemical properties, and biological environment suitable for crop growth resulted in higher $\mathrm{C}$ sequestration. The rate $\left(\mathrm{kg} \mathrm{C} \mathrm{ha}^{-1}\right.$ year $\left.^{-1}\right)$ of increase was calculated with reference to the baseline SOC pool at the start of the experiment. It was observed that $\mathrm{C}$ balance rate was the highest with INM amendment and lowest with nontreated control. Organic C inputs were higher than outputs for INM, resulting in higher C sequestration. INM contains most of the carbon in recalcitrant form resulting in more sequestration, as it has already been subjected to some decomposition before application in agricultural fields ${ }^{23}$.

Figure 3 shows the annual yield (10 years) of paddy. Nutrient management practices have significant effect on grain yield. The highest grain yield was obtained for INM. Three years of application of PM alone or in combination with urea at different $\mathrm{N}$ levels significantly increased wetland rice yield ${ }^{24}$. Liu et $a .^{25}$ also reported that organic amendments (17 years) increased rice yields, SOC and soil N compared to NPK application. In the 


\section{RESEARCH ARTICLES}

present study, after the sixth year of INM, an increasing trend of paddy yield was observed, whereas a yield plateau trend was found in the balanced chemical fertilizer application. An increasing trend of grain yield might be the resultant effect of increasing soil carbon stock in INM.

\section{Conclusion}

Data obtained from long-term soil analyses using the DNDC and DSSAT models proved that INM is superior compared to balanced chemical fertilizer treatment to increase soil carbon stock, paddy yield, microbial population and $\mathrm{C}$ sequestration. Carbon losses to the environment were high, but total carbon balance was positive in INM. A significant positive correlation $(r=0.94)$ was found between $\mathrm{C}$ content of MWDw and soil bacterial population, which proved positive contribution of soil bacteria for $\mathrm{C}$ sequestration. Carbon mineralization rate

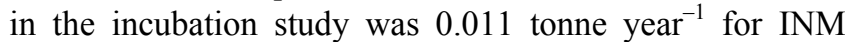
which was lower than the values obtained in the DNDC and DSSAT models. Comparing the two models, DNDC is better than DSSAT for prediction of SOC balance.

Disclosure statement: No potential conflict of interest was reported by the authors.

1. Karlen, D. L., Andrews, S. S. and Doran, J. W., Soil quality: current concepts and applications. Adv. Agron., 2001, 74, 1 e40.

2. IPCC, Climate Change 2001: Impacts, Adaptation and Vulnerability: Contribution of Working Group II to the Third Assessment Report of the IPCC (eds McCarthy, J. J. et al.), Cambridge University Press, Cambridge, UK, 2001, p. 1000.

3. Sun, W., Huang, Y., Zhang, W. and Yu, Y., Carbon sequestration and its potential in agricultural soils of China. Global Biogeochem. Cycles, 2010, 24, 12; http://dx.doi.org/10.1029/ 2009GB003484.

4. Porter, J., Costanza, R., Sandhu, H., Sigsgaard, L. and Wratten, S., The value of producing food, energy, and ecosystem services within an agro-ecosystem. Ambio, 2009, 38, 186-193.

5. Tsuji, G. Y., Uehara, G. and Balas, S., Decision Support System for Agrotechnology Transfer (DSSAT) Version 3, University of Hawaii, Honolulu, Hawaii, USA, 1994.

6. Jones, J. W. et al., The DSSAT cropping system model. Eur. J. Agron., 2003, 18, 235-265.

7. Hoogenboom, G. et al., Decision Support System for Agrotechnology Transfer (DSSAT) Version 4.5 [CD-ROM], University of Hawaii, Honolulu, Hawaii, USA, 2010.

8. Pathak, H., Li, C. and Wassmann, R., Greenhouse gas emissions from Indian rice fields: calibration and upscaling the DNDC model. Biogeosciences, 2005, 2, 113-123.

9. Naher, U. A., Radziah, O., Shamsuddin, Z. H., Halimi, M. S. and MohdRazi, I., Isolation of diazotrophs from different soils of Tanjong Karang rice growing area in Malaysia. Int. J. Agric. Biol., 2009, 11, 547-552.

10. Kemper, W. D. and Rosenau, R. C., Aggregate stability and size distribution. In Methods of Soil Analysis (ed. Klute, A.), Part 1.2nd ed. Agron. Monogr. 9. ASA, 1986, Madison, WI, USA, 1986, pp. 425-442.

11. Walkley, A. and Black, I. A., An examination of the Degtjareff method for determining soil organic matter, and a proposed mod- ification of the chromic acid titration method. Soil Sci., 1934, 37 29-38.

12. Olivier, C., Devevre, O. C. and Horwath, W. R., Decomposition of rice straw and microbial carbon use efficiency under different soil temperatures and moistures. Soil Biol. Biochem., 2000, 32, 17731785 .

13. Bending, G. D., Turner, M. K. and Jones, J. E., Interactions between crop residue and soil organic matter quality and the functional diversity of soil microbial communities. Soil Biol. Biochem., 2002, 34, 1073-1082.

14. Wang, R., Zhang, H., Sun, L., Qi, G., Chen, S. and Zhao, X., Microbial community composition is related to soil biological and chemical properties and bacterial wilt outbreak. Sci. Rep., 2017, 7(1), 343; 10.1038/s41598-017-00472-6.

15. Li, J. T. and Zhang, B., Paddy soil stability and mechanical properties as affected by long-term application of chemical fertilizer and animal manure in subtropical China. Pedosphere, 2007, 17, $568 \mathrm{e} 579$.

16. Manna, M. C., Swarup, A., Wanjari, R. H., Mishra, B. and Shahi, D. K., Long-term fertilization, manure and liming effects on soil organic matter and crop yields. Soil Tillage Res., 2007, 94, $397 \mathrm{e} 409$.

17. Li, J. T., Zhong, X. L., Wang, F. and Zhao, Q. G., Effect of poultry manure and livestock manure on soil physical and biological indicators in a rice-wheat rotation system. Plant Soil Environ., 2011, 57, 351e356.

18. Ouyang, L., Wang, F., Tang, J., Yu, L. and Zhang, R., Effects of biochar amendmenton soil aggregates and hydraulic properties. J. Soil Sci. Plant Nutr., 2013, 13, 991e1002.

19. Are, K. S., Ayodele, Adeleye, E. O., Fademi, I. O. and Aina, O. A., Improving physical properties of degraded soil: potential of poultry manure and biochar. Agric. Nat. Res., 2017, 51, 454-462.

20. Puttaso, A., Vityakon, P., Saenjan, P., Trelo-ges, V. and Cadisch, G., Relationship between residue quality, decomposition patterns, and soil organic matter accumulation in a tropical sandy soil after 13 years. Nutr. Cycling Agroecosyst, 2011, 89, 159e174.

21. Are, K. S., Adelana, A. O., Adeyolanu, O. D., Oyeogbe, I. A. and Adelabu, L., Comparative effects of vetiver grass (Chrysopogon zizanioides) strips, vetiver mulch and veticompost on soil quality and erodibility of a sloping land. Agric. Trop. Subtrop, 2012, 45, $189 \mathrm{e} 198$.

22. Adeleye, E. O., Ayeni, L. S. and Ojeniyi, S. O., Effect of poultry manure on soil physico-chemical properties, leaf nutrient contents and yield of yam (Dioscorea rotundata) on alfisol in southwestern Nigeria. J. Am. Sci., 2010, 6, 871e878.

23. Benbi, D. K. and Senapati, N., Soil aggregation and carbon and nitrogen stabilization in relation to residue and manure application in rice-wheat systems in northwest India. Nutr. Cycling Agroecosyst., 2009, 87, 233-247.

24. Bijay-Singh, Yadvinder-Singh, Maskina, M. S. and Meelu, O. P., The value of poultry manure for wetland rice grown in rotation with wheat. Nutr. Cycling Agroecosyst., 1997, 47, 243-250.

25. Liu, M., Li, Z., Zhang, T., Jang, C. and Che, Y., Discrepancy in response of rice yield and soil fertility to long-term chemical fertilization and organic amendments in paddy soils cultivated from infertile upland in subtropical China. Agric. Sci. China, 2011, 10(2), 259-266.

ACKNOWLEDGEMENTS. We thank Bangladesh Rice Research Institute and CRPII (KGF-funded) project.

Received 31 January 2019; revised accepted 9 October 2019

doi: $10.18520 / \mathrm{cs} / \mathrm{v} 118 / \mathrm{i} 4 / 587-592$ 